\title{
Who does nothing spoils nothing!
}

\author{
Eva Mydlíková ${ }^{1}$, Peter Patyi²
}

\author{
${ }^{1}$ Department of Social Work, Trnava University in Trnava, Univerzitné nám. 1, 91843 Trnava, Slovakia \\ Email: eva.mydlikova@truni.sk \\ ${ }^{2}$ Department of Social Work, Trnava University in Trnava, Univerzitné nám. 1, 91843 Trnava, Slovakia \\ Email: peter.patyi@truni.sk
}

\begin{abstract}
This article has been aimed at presenting a repertoire of mistakes made by two groups of experts at preparation, implementation and evaluation of preventive program focused on the increase of children and youth sensitivity to violence in the school environment. It was a group of researchers from the university, and a group of prevention supporters, herein as preventists, from a big non-profitable organization. The two groups worked together in various extents and within various stages of large preventive program application. Preventists from the non-profitable organization required from the researchers to map the program efficiency at elementary schools students. Both researchers and preventists created a tool for identification of children's attitude to violence. Preventists created their own preventive program that was applied at schools during 8 sessions. Before and after the preventive program attending, the children filled in the same questionnaire of attitude in order to capture the change of their attitude to violence. Reverse analysis of preventive program test results represented a method of obtaining the outputs in order to identify the preventive program efficiency before and after the program application on students and pupils of a single Slovak region. So called ,structural type errors " were identified during detail analysis of preventive program efficiency test results. They are errors made by the group of researchers and preventists in the area of coordination and cooperation in the stage of preparation and implementation of the preventive program.
\end{abstract}

Keywords-Rechearch. Preventive programs. Children. Youth.. Violence.

\section{INTRODUCTION}

Approx. a third of six billion inhabitants of the planet Earth refer to children. The Public Healthcare Office stated on its website (World Health Organization, 2018) that as much as $21 \%$ of children in Central Europe and $16 \%$ of children in Western Europe have encountered physical violence. Regarding the violence on children subject matter, Slovakia has lagged behind in the area of research and also in implementation of preventive and intervention programs. Extensive research on home violence committed on kids in the Slovak Republic was performed rarely and sporadically ${ }^{1}$. Based on their longterm experience, the Czech and Slovak pediatricians (Škodáček, 2015; Slaný, 2008; Koval', 2001 and Fedor a kol., 2013) stated that violence at children has actually increased during the last years ${ }^{2}$. School is for a child the environment just behind the family where he or she

\footnotetext{
${ }^{1}$ In 1999 (Slonad) with sample of 5230 children, in 2013 (Research Institute of Children Psychology and Patopsychology in cooperation with the Institute of Labor, Social Matters and Family) with sample of 1560 children.

${ }^{2}$ Pediatria pre prax, 2015:16, 23 Overview articles. Searched on Oct 04, 2016, available on www.solen.sk
}

spends most time and that influences him/her significantly. Two big researches were conducted in Slovakia in this area (Bieliková a kol., 2009; Pétiová, 2014). Violence in educational environment (school violence, violence committed at school) has various forms and is based on various factors (Thompson, 1994; Osborne, 2004; Ascher, 1994; Kolár, 2001; Leymann Gustafsonn, 2014; Holubová, 2006). This article is aimed at presenting some research findings related to the repertoire of mistakes that the preventive program authors can make despite of good intentions.

Non-profitable organization has been professionally working with violence victims in almost whole Slovakia for a long time. More than 20 - year history of the organization in the area of crisis intervention in the violence victims initiated the preparation and implementation of a few preventive programs. They were very rare and short - term events at first, later developed in complex and meaningful programs. Seven workers of the non-profitable organization preventive center implemented the preventive program during period of years 2016 - 2017 in cooperation with headquarters of two elementary schools and one technical high school in 
the region. They dedicated an hour to work with violence in each of selected classes within eight weeks. The program was built on participation techniques, drawings, role play boundaries and presentation of short films. Preventive program was aimed at teaching children and the youth not to accept any expressions of violence. Techniques developing perception of emotions, ability to solve conflicts, supporting assertive behavior and increasing self-conscience were applied, as well as techniques aimed at teaching kids to cooperate. The lecturers made efforts to mediate information to the children on the forms and expressions of violence. However, the organization management was rather interested in the program efficiency, thus they asked our office for cooperation in monitoring of the program advis ability.

Our university workplace tested the preventive program efficiency.

We elaborated the fundamental research question: Will the preventive program influence the perception of violence on children and adolescents? in the following partial research questions:

Q1: Will the program effects be reflected in the perception of violence against the respondent and other persons?

Q2: Will the preventive program effects be different when considering respondents' sex?

Q3: How will the respondent's age effect on the change at the perception of violence expression be reflected after the passed program?

Respondents were chosen in the target group upon purposely quota selection. The quota signs referred to sex, age, education/ school and passed preventive program. The first group consisted of students of two elementary schools (3rd - 9th grade) and the second group consisted of students of a technical high school (1st - 4th grade). All schools were located in a single Slovak region. Identical questionnaire was applied in the classrooms before and after the preventive program implementation. Thus, basic sample of elementary schools comprised originally of 286 respondents and total 206 respondents after final data adjustment (112 girls, and 94 boys), which refers to $72.03 \%$ share on basic sample. Based on the calculations, 266 respondents represented the most suitable value of the selection group. In this case we didn't reach the required share of selection group compared to the basic group.

Basic sample of the high school consisted of 489 respondents vs 188 of them after final data adjustment (117 girls and 70 boys), which refers to $38.45 \%$ share on basic sample. Based on the calculations, 375 respondents represented the most suitable value of the selection group. We didn't reach it because of too high fluctuation in particular classrooms. However, referring to Reichel (2009, p.87), $40 \%$ of selected group to the basic group is relevant in case of research made with up to 1,000 units.

\section{DATA COLLECTION METHOD}

We used own producer questionnaire during tests that we applied to the same pupil/ student before and after the preventive program application. Questionnaire was structured so that particular items were grouped in 4 categories. In the first category, we examine a respondent's tolerance to 18 particular expressions of physical (6 items) and psychical (7 items) violence against the respondent within 5-mark scale, and there are 5 reverse control questions. The 2 nd category monitors the respondent's ability to perceive 4 expressions of negligence. The 3rd category contains only one item monitoring the tolerance of expressions of sexual violence against respondent. The last, fourth category examines the respondent's tolerance of violence committed on other persons where 7 items relate to physical violence, 6 items relate to psychical violence and there are also 9 reverse control questions.

Questionnaire variants for children and youth contain small stylistic modifications adapted to the respondents' age.

\section{PROCESSING OF RESULTS}

Data obtained were statistically processed with SW IBM SPSS Statistics v. 22.0.0. Significant correlations between the variables were tested on the importance level $\mathrm{p}=0.05$. Standard and relevant statistical tests were used for identification and analysis of particular relations or differences. Since it was 5-item scale, we chose classical arithmetical mean for presentation of results since median and modus are principally the same and their value corresponds to the mean value including all respondents. Coefficient of reliability „Cronbach a“ is adequate in initial questionnaire, indicating acceptable reliability of respondents' answers to particular questions. Reliability is slightly lower in case of final questionnaire.

\section{RESEARCH OUTCOMES}

Results stated below were structured according to 3 research questions that we had allocated 1 zero a 3 working hypotheses before that are not stated here because of low significance.

V1: We would like to know whether and in what extent 
the preventive program will influence perception of violence on children and adolescents committed against oneself (question category 1) or against other persons (question category 4). Based on the analysis of mean values of elementary and high school students' responses classified in particular grades on the statements of category 1 (they do it to me) before and after application of preventive program, it is apparent that the differences in all respondents' replies are negligible in order to confirm the work hypothesis on likely non-existent significant difference between particular tests (i.e. after and before program application). Following the score calculation from all tests, we applied Student T-test for two dependant selections for more detail differential analysis. Test significance value referred to $\mathrm{p}=.736>0.05$. Thus, statistically significant difference doesn't exist in this case between the results of initial and final test and it confirmed our work hypothesis. This assumption was verified through testing of particular items. That means, we tested each item within the initial questionnaire individually and matched it against the same question in the final questionnaire with the help of Wilcoxon pair test. No case confirmed statistically significant difference between the initial and final questionnaire results.

Analyzing the mean values in detail, we can see that the students responded to particular questions in rather reliable way, and positively, as seen by ,lecturer preventist". We see many reasons thereof but the most principal one can refer to the fact that the statements relate directly to particular respondent. That means, students in fact don't accept various forms of violence against oneself. It was realized from detail analysis (ANOVA) that there are no significant differences $(\mathrm{p}=221>0.05$ - initial test and $\mathrm{p}=.084>0.05$ - final test resp.) in the initial and final questionnaire of all respondents among particular grades.

V2: Will the preventive program effect be different when considering respondents' sex? Statistically significant differences were demonstrated between the sexes and particular elementary schools. Reviewing the initial and final tests based on sex (Student T-test for two independent selections), there is significant difference between girls and boys ( $\mathrm{p}=0.03<0.05$-initial test resp. $\mathrm{p}=0.01<0.05$ - final test). While we cannot state that there is significant difference at one or another sex in particular questionnaires' results before and after passing the preventive program; it is however apparent that girls reach much higher score than boys in both, initial and final questionnaires. It means that girls express their assessment of the stated situations more clearly towards socially conforming required attitude and less accept the forms of adverse conduct against them.

Considering particular elementary schools, we talk about significant difference $(\mathrm{p}=0.002<0.05$ - initial test resp. $\mathrm{p}=0.007<0.05-$ final test) that indicates stronger assessment of particular items by students from one elementary school than those from the other elementary school. It means that students from the first elementary school reject more various forms of adverse conduct against them in the terms of questionnaire. If we want to compare particular items within the 1st category of questions, e.g. physical and psychical violence, the results indicate that there is no statistically important difference in the initial and final questionnaire within total score of the whole set of statements, nor is there statistically important difference in comparison of particular units (Student T-test for two independent selections: Physical violence - $\mathrm{p}=.385>0.05 ; \quad$ Psychical violence $\mathrm{p}=.731<0.05$ ). Both physical and psychical violence correlate to each other significantly (Pearson $r=.705$; $\mathrm{p}=.000$ ). Since we were aware of the energy dedicated to the preventive program implementation by the workers, we tried to analyze particular respondents' statements in relation to particular variables (age, sex) with the aim to find at least some elements of positive influence of the preventive program on the respondents' opinions so as even minimum differences in particular answers help us draw some (might be latent) tendencies of respondents' behavior in certain situations. Major progressive shift was seen in humiliation through published unflattering photography or other information on a respondent's person on Internet web, in insulting and unacceptable touching.

Similar to respondents from elementary schools, average answers of respondents from high school varied within socially comfortable space, i.e. acceptation of adverse conduct towards oneself is rather low. Contrary to elementary schools, we identified statistically significant difference in results of initial and final questionnaire (Student T-test for two dependent selections) $(\mathrm{p}=.007<0.05)$. We have to check the calculations again and analyze in detail particular items in the questionnaire between the initial and the final test (Wilcoxon pair test).

Detail analysis of resulting answers in category 4 (committed violence on the others), and namely testing (Student T-test for two dependent selections) showed that such minimum differences are statistically significant $(p=.000<0.05)$ despite of very similar average items in both initial and final test. Thus, we can presume that respondent's statements evaluation has changed after passing the preventive program. We have to interpret these results very carefully since in fact we cannot 
identify whether the change depended on preventive program. We also have to take in account that the respondents' answers in the initial and the final test vary within desirable comfortable zone and students answer the questions in fact positively, as seen by the ,lecturer preventist", which could have resulted from a few factors. One of them indicates that the students simply revealed the questionnaire meaning and answered the questions in a „desirable“ way. Another option simply refers to students' ,awareness" and the way of thinking that reflects the positive status of perception of adverse behavior towards other people by elementary schools' students. It is again up to interpretation and evaluation of the research tool. We applied Wilcoxon pair test to check and detail analysis of particular statements within initial and final questionnaire but it only demonstrated a single statistically significant difference, namely in the last item ,accept the other how he is “ $(\mathrm{p}=.030<0.05)$. Thus, major change at evaluation related only to a single item. Total result indicates significant differences between the initial and final questionnaire, but detail analysis didn't confirm the result unambiguously. It could have been caused by various factors; from lower reliability of filled in questionnaires up to low effectiveness of the preventive program. Within the differences in answers in the category 4 questions, significant difference was confirmed between girls and boys (Student T-test for two dependent selections) in the initial questionnaire $(\mathrm{p}=.001<0.05)$ and final questionnaire $(\mathrm{p}=.046<0.05)$, where the girls again showed lower acceptation of adverse behavior, as in case of the first test, now towards other persons.

V3: How will the respondent's age effect on changed perception of violence expressions be expressed after the program passing?

As in the category 1, no significant differences were confirmed (ANOVA) between the initial and final questionnaire results, considering the grade the students attend $(p=.202>0.05$ - initial; $p=.130>0.05$ - final $)$. Similar to the 1st category of questionnaire questions, significant difference was confirmed also in the last category in the results between particular elementary schools. In case of initial $(p=.000<0.05)$ and final $(\mathrm{p}=.003<0.05)$ questionnaire, students of one elementary school demonstrated significantly lower acceptation of adverse behavior towards other persons than students from the other elementary school. In particular areas of physical $\quad(p=.660>0.05) \quad$ and psychical $\quad(p=.351>0.05)$ violence, no difference was confirmed between the initial and final questionnaire (Student T-test for two dependent selections).
In case of category 4 of questions, no statistically significant difference was confirmed within total results of the initial and final questionnaire (Student T-test for two dependent selections $\mathrm{p}=.881>0.05$ ) at the students of high school.

In order to check particular statements to one another within the initial and final questionnaire, we applied the Wilcoxon pair tests also in this case and it confirmed statistically significant difference in two items, namely ,publishing of inadequate photo that humiliates somebody, $(\mathrm{p}=.046<0.05)$ and item ,, be interested in the others" $(\mathrm{p}=.018<0.05)$. Like in the first category, no significant differences were confirmed (ANOVA) between the initial and final questionnaire results, considering the grade the students attend $(\mathrm{p}=.617>0.05$ initial; $\mathrm{p}=.572>0.05$ - final).

Within the differences in answers in the category 4 questions based on sex, significant difference was confirmed between girls and boys (Student T-test for two dependent selections) in the initial questionnaire $(p=.002<0.05)$ and final questionnaire $(p=.000<0.05)$, where the girls again showed lower acceptation of adverse behavior, as in case of the first test, now towards other persons.

In particular areas of physical $(p=.646>0.05)$, psychical $(\mathrm{p}=.567>0.05)$ and sexual $(\mathrm{p}=.081>0.05)$ violence, no difference was confirmed between the initial and final questionnaire (Student T-test for two dependent selections).

Taking in account the respondent', s age/ school grade attended, we received a few results. Differences in the answers based on school grade attended were tested with Kruskal-Wallis test. We received a few interesting significant results - differences in the answers based on school grade attended, which require detail interpretation. The principle is the same as in case of comparison according to sex. We chose a few of them. We compared results reached during pre- and post- Mean Rank testing of students of two elementary schools, finding out that measured values dropped four times at 3rd grade students compared initial and final test, in case of different answers to six expressions of aggressive behavior (they bite you, pull you, kick you down, profane you, grumble on you and touch you) as if the opposite effect was perceived and the program resulted in lowered aggression perception. As for 4 grade students, all values rose but one (they kick you down); three values dropped at 5 . grade students (he bite you, pulled you and touched you) and three values rose, two values dropped at 6. grade students (he kicked you down and grumbled on you), two values dropped at 7.grade students (he kicked you down 
and pulled you), two values dropped also at 8.grade students (he kicked you down and grumbled on you) and three values dropped at 9. grade students (he bite you, pulled and touched you) and three values rose (he kicked you down, profaned and grumbled on you). Intense shifts were reported upwards and downwards in all grades at item ,he kicked you down“. Students of the 4. grade demonstrated the major shift in particular items before and after the program application (5 of 6 items) vs the smallest shift reported at the 3. grade students (2 of 6 items). Within particular items, most positive shift (5 of 6) was reported in the item ,they kicked you down“" and item ,touched you“, and the smallest shift (3 of 6) in the item ,they pulled you“. As in the 1. category (they do it to me), no significant differences were confirmed in the 4 . category (they do it to somebody) (ANOVA) between the initial and final questionnaire results, considering the grade the students attend $(p=.202>0.05$ - initial; $\mathrm{p}=.130>0.05$ - final). Detail analysis of particular questionnaire items revealed that the students of the 3rd grade were those least positively responding to with only two items with rising values (ask for money and insult him) after the program passing. The values dropped even more in the remaining five items as if the program has had an opposite effect. Similar results were reported at students of 5. grade (two positive responses) and 4. grade students (three positive responses) Contrary to our presumptions, it seems that application of this particular program was more efficient at students of higher grades, namely at students of 7 . grade (all 7 items). All students responded most sensitively to the item ,they insulted him“. Significant difference was reported in results between particular elementary schools. In both initial $(p=.000<0.05)$ and final $(p=.003<0.05)$ questionnaire, students of one elementary school demonstrated significantly lower acceptation of adverse behavior towards other persons than students of the other elementary school.

Respecting the questionnaire structure, we should interpret the results of the 2nd category of questions (neglecting) and the 3rd category of questions (sexual misusing). The 2 nd category consisted of 4 statements that should signalize neglecting as one of the violence forms. They were directed outwards a respondent, i.e. whether he/ she reported any expressions of neglected kids in the surroundings. This section of the questionnaire was disproportional and its results have small narrative value. Students responded to the questionnaire items with average values ,I don't know“. Median reached value ,, " in the first item and ,2" in the other items. Modus reached value " 3 " in all items.
Validity of this battery is questionable. Reliability of Cronbach's a $=.65$ (pre-test) resp. Cronbach's a $=.66$ (post-test) is rather small at the given sample of respondents. Lower reliability at the questions is probably associated with unclear validity of the battery. The check out the results, we applied Chi-quadrate test of good conformance $\mathrm{p}=.000<0.05$ to all questions in both initial and final questionnaire), indicating that the differences in answers are statistically significant. Thus, we can interpret the result so that it wasn't demonstrated by such determined category of questions that the children reported some forms of neglecting in their surroundings. Sex-based significant differences in the answers before and after the questionnaire (Chi- quadrate test) were identified in the items ,they don't attend canteen, nor do they bring snack from home" $(\mathrm{p}=.05=0.05)$ and ,, they never have money with them" $(\mathrm{p}=.038<0.05)$. It seems that boys and girls have different perception of items that are associated with economic backgrounds of their mates. It is interesting that similar significant differences were reported when dividing students according to school grade attended, but only in the item ,they never have money with them " $(\mathrm{p}=.013<0.05)$.

The 3. category of questionnaire - sexual harassment contained only one item. In total, the area of sexual harassment was elaborated in the questionnaire so that particular conclusions are very hard to draw from. One item in this area is also included in the 1. category of questions, defined as a different type of variable for required calculation. On the other hand, the 3. category contains only one item that includes dichotomy variable. Based on such constructed questions, particular conclusions cannot be summed up and generalized when compared to other areas. To test this item, we applied binomial test that proved that there is a significant difference in the respondents' answers in both questionnaires. All respondents answered the question in unambiguously rejecting way.

\section{CONCLUSIONS}

After the questionnaires testing completion we found out no significant effect of preventive program and decided to trace backwards whether the questionnaire was adjusted and if yes, how, and how the preventive program was structured. The research processing was aimed at finding out the effect of particular preventive program on the change at violence perception towards oneself and the others by students/ pupils and adolescents. The results are not overwhelming but useful anyway, for researchers and preventists in their professional praxis for purpose of new programs compilation. 
Three circles of outputs have been identified, signalizing the reasons of not reached required effect: the questionnaire structure, preventive program structure and their mutual correlation.

Based on extensive experiences from the crisis intervention, preventive center staff prepared a series of particular techniques that children could find interesting and that could help eliminate violence among them. Researchers presumed that if the preventive program should be aimed at positively influencing the violence perception by children, preventists should be able to compile particular program section so as the goal was reached. While the preventists set forth the goals of particular program classes, the whole missed a common goal. Absence thereof „broke“ the entire program structure down to 8 interesting and dynamic 1-hour taking sessions, which however missed the direction and complex meaning.

The researchers compiled the questionnaire according to „narration“ of that what should have been, as said by experienced preventists, a goal of the preventive program. Researchers didn't participate on either program methodology preparation or its implementation. They compiled the questionnaire together with preventists and presumed that the preventive program contents would correspond to information content in the questionnaire. Researchers only presumed that the preventive program will include presentation of violence forms and protection of children against violence, thus they compiled the questionnaire according to particular violence expressions.

The questionnaire was originally compiled for a sample of younger students. Since the program was appreciated at schools, preventists extended it to higher elementary school grades and to a high school. Preventists adapted the stylization of particular statements to the high school language but the whole questionnaire structure was insufficient to adequately formulate questions to cover all 11 grades since there are too big age differences. The questionnaire could have been perceived very transparently in the higher grades and their respondents answered questions in a socially adequate way.

Preparation of disproportional questionnaire represented another fault since it represented four various areas in disproportional way. Thus, both the questionnaire and the program „lived their own lives“ without meeting each other. Researchers tested the program before and after but the program wasn't primarily focused on violence, thus the expected positive effect of the program didn't show up.

Who does nothing spoils nothing! Good praxis requires cooperation of researchers and experts. To make the program implementation meaningful, the following principles should be observed:

a) compile the program methodology taking in account the organization goals,

b) compile measuring technique (questionnaire) according to an existing methodology and the organization goals,

c) researchers should participate on the first program applications in order to test the extent of topic grasping and compliance with the goal,

d) eventual interventions in the questionnaire structure should be made after mutual agreement of researchers and implementers of the program,

e) prepare a few variants of the questionnaire, taking in account the respondents' age, maintain proportionality of particular monitored categories .

Authors usually present their success in monographs. So did us, since we consider a huge success when experts contact researchers with request for cooperation and researchers are able to reflect mistakes they made.

\section{ACKNOWLEDGEMENTS}

This article has been developed with the support of Slovak Research and Development Agency trough the project APVV-16-0205 Identification of mechanisms of early CAN syndrome diagnostics.

\section{REFERENCES}

[1] Ascher, C. (1994). Gaining Control of Violence in the Schools: A View from the Field. ERIC Digest, 1994, No.100. ED377256.

[2] Hiriogen, M. F. (2002). Psychické násilí v rodine a na pracovišti. Praha: Academia

[3] Holubová, B. (2006). Šikanovanie a sexuálne obt’ǎovanie na pracovisku. Záverečná správa. VÚ 2214, 2006

[4] Horváth, G. (2001). Mobbing - šikanovanie na pracovisku. Rodina a škola (ISSN : 0231 - 6463), 49(8)

[5] Hubertová, M. (1995). Psychický teror na pracovišti: Mobbing a další druhy násilí na pracovišti. Psychologie v ekonomické praxi (ISSN 0033-300X), 40(3-4)

[6] Kolár, M. (2001). Bolest škanování. Praha: Portál

[7] Koval', Š. (2001). Týranie starých l’udí. Košice: Pont

[8] Lednická, J. (2002)Psychologické aspekty mobbing. Praha: FF UK KPS

[9] Leymann, H., Gustafsson, A. (2014). Why Nurses Commit Suicide: Mobbing in Health Care Institutions. Edwin Mellen Press

[10] Leymann, H. (1966). The Content and Development of Mobing at a Work. European Journal of Work and Organizational Psychology. Tay lor and Francis Ltd. 
[11] Osborne, J. W. (2004). Identification with Academics and Violence in Schools. Review of General Psy chology (ISSN : 1089-2680), 8(3)

[12] Poliach, V. (2006). Pojmy "násilie" a "agresia" v kontexte edukačnej reality. In Zborník príspevkov z Medzinárodnej konferencie "Duričove dni": Násilie na školách

[13] Reichel, J. (2009). Kapitoly metodologie sociálních výzkumú. Praha: Grada

[14] Říčan, P. (1993). Šikanování jako psychologický problem. Československá psy chologie (ISSN 0009-062X), 37(3)

[15] Slaný, J. (2008). Syndrom CAN: syndrome týraného dítěte. Ostrava: Ostravská univerzita

[16] Spurný, J. (1996). Psy chologie násilí. Praha: Eurounion

[17] Škodáček, I. (2015). Prejavy CAN syndrómu (týraného, bitého a zanedbávaného diet'at'a) u detí v ambulancii pediatra. Pediatria pre prax (ISSN : 1339-4231), 16(1), http://www.solen.sk/pdf/047f5e58f922ea4ffc79851e92515 889.pdf

[18] Thompson, L. (1994). One Incident is Too Many. Policy Guidelines for Safe Schools. SSTA Research Report 94-05 